\title{
GRASP wt Allele
}

National Cancer Institute

\section{Source}

National Cancer Institute. GRASP wt Allele. NCI Thesaurus. Code C115267.

Human GRASP wild-type allele is located in the vicinity of $12 q 13.13$ and is approximately 9 $\mathrm{kb}$ in leng th. This allele, which encodes general receptor for phosphoinositides 1associated scaffold protein, is involved in synaptic receptor localization. 